\title{
PARTISIPASI MASYARAKAT DALAM SISTEM KEAMANAN LINGKUNGAN UNTUK MENINGKATKAN KEAMANAN DAN KETERTIBAN MASYARAKAT
}

\author{
Neysa Amallia \\ Fakultas Ilmu Sosial dan Ilmu Politik Universitas Sang Bumi Ruwa Jurai \\ neysaamallia@gmail.com
}

\begin{abstract}
ABSTRAK
Tujuan dari penelitian ini adalah untuk mengetahui bagaimana bentuk partisipasi masyarakat dalam sistem keamanan lingkungan dan untuk mengetahui tingkat keamanan dan ketertiban masyarakat pada Kelurahan Sukamenanti Kecamatan Kedaton Kota Bandar Lampung. Metode yang digunakan dalam penelitian ini adalah Kuantitatif. Analisa yang digunakan untuk menganalisis data adalah analisis kuantitatif, menggunakan rumus distribusi frekuensi. Teknik pengumpulan data yang penulis gunakan adalah Kuesioner, Interview dan Dokumentasi. Berdasarkan hasil penelitian bahwa partisipasi masyarakat dalam pelaksanaan Sistem Keamanan Lingkungan di Kelurahan Sukamenanti Kecamatan Kedaton Kota Bandar Lampung telah berperan aktif dalam meningkatkan ketertiban dan keamanan. Pihak kepolisian sebagai inti kekuatan dan sekaligus sebagai pembina keamanan dan ketertiban beserta masyarakat dapat ikut serta bertanggung jawab terhadap keamanan dan ketertiban seluruh anggota masyarakat, sehingga dapat terpeliharanya ketertiban dan keamanan lingkungan.
\end{abstract}

Kata kunci : partisipasi, keamanan, ketertiban

\begin{abstract}
The purpose of this study is to determine how the form of community participation in the environmental security system and to determine the level of security and public order in Sukamenanti Village, Kedaton District, Bandar Lampung City. The method used in this research is quantitative. The analysis used to analyze data is quantitative analysis, using the frequency distribution formula. Data collection techniques that the authors use are questionnaires, interviews and documentation. Based on the results of research that community participation in the implementation of the Environmental Security System in Sukamenanti Village, Kedaton District, Bandar Lampung City has played an active role in improving order and security. The police as the core of power and at the same time as the guiding of security and order along with the community can participate in being responsible for the security and order of all members of the community, so as to maintain order and environmental security.
\end{abstract}

Keywords: participation, security, order

\section{PENDAHULUAN}

Penciptaan keamanan dan masyarakat juga dapat mengambil ketertiban masyarakat bukan hanya bagian dalam menciptakan keamanan pelaksanaan perundang-undangan dan dan ketertiban, minimal di dominasi aparat penegak hukum, lingkungannya masing-masing. 
Masyarakat mempunyai pengaruh yang kuat terhadap pelaksanaan keamanan dan ketertiban, sehingga sangat diperlukan kesadaran hukum masyarakat.

Kegiatan Siskamling merupakan wadah bagi masyarakat untuk berpartisipasi dalam meningkatkan kesadaran hukum dan penegakan supremasi hukum. Pengamanan lingkungan tersebut akan optimal apabila masyarakat turut berpartisipasi secara aktif.

Pentingnya partisipasi masyarakat dalam pelaksanaan sistim keamanan lingkungan didasarkan pada adanya fenomena kejahatan dalam kehidupan masyarakat yang semakin kompleks, diantaranya maraknya aksi begal yang terjadi.

Selain aksi begal terdapat pula aksi pencurian di malam hari, dan masalah terakhir adalah seringnya ditemukan warga yang menerima tamu di malam hari sehingga membuat warga lain resah. Hal ini tentu saja akan berpengaruh negatif, karena warga lain akan merasa curiga dan khawatir terhadap tamu yang diterima.
Upaya untuk mewujudkan ketertiban dan keamanan di masyarakat, tidak dapat hanya dengan mengandalkan aparat saja. Selain jumlah aparat yang terbatas, juga cakupan tugas yang harus diemban aparat sangat banyak. Untuk itu peran serta masyarakat sangat dibutuhkan guna membantu kelancaran tugas-tugas aparat di lapangan. Melalui tokoh-tokoh masyarakat yang berkaitan langsung dengan masyarakat, tugas dan fungsi aparat dapat dioptimalkan.

Beranjak dari latar belakang tersebut, maka yang menjadi permasalahan dalam penelitian ini adalah : Bagaimana partisipasi masyarakat dalam sistem keamanan lingkungan untuk meningkatkan keamanan dan ketertiban masyarakat pada Kelurahan Sukamenanti Kecamatan Kedaton Kota Bandar Lampung.

Tujuan dari penelitian ini adalah untuk mengetahui bagaimana bentuk partisipasi masyarakat dalam sistem keamanan lingkungan dan untuk mengetahui tingkat keamanan dan ketertiban masyarakat pada Kelurahan Sukamenanti Kecamatan Kedaton Kota Bandar Lampung. 


\section{METODOLOGI PENELITIAN}

Metode yang digunakan dalam penelitian ini adalah Kuantitatif. Lokasi penelitian ini di Kelurahan Sukamenanti Kecamatan Kedaton Kota Bandar Lampung. Analisa yang penulis gunakan untuk menganalisis data adalah analisis kuantitatif, menggunakan rumus distribusi frekuensi. $\quad$ Teknik pengumpulan data yang penulis gunakan adalah Kuesioner, Interview dan Dokumentasi. Teknik pengolahan data dilakukan dengan cara Editing, Klasifikasi data (coding), Tabulasi.

Sampel yang digunakan dalam penelitian ini dilakukan secara Random Sampling, untuk menentukan banyaknya sampel dalam penelitian ini digunakan rumus perhitungan besaran sampel dari Taro Yamane (Rakhmat dalam Riduwan, 2004: 65) sebagai berikut :

$n=\frac{N}{N \cdot d^{2}+1}$

Sehingga secara keseluruhan jumlah sampel yang menjadi responden sebanyak 88 responden.

\section{HASIL DAN PEMBAHASAN}

Data yang akan penulis analisis adalah sebagai berikut :

\section{Bentuk Partisipasi Masyarakat \\ Dalam Sistem Keamanan Lingkungan}

Masyarakat dalam sistem keamanan lingkungan diukur berdasarkan teori Bentuk Partisipasi menurut Hamijoyo (2007: 21), dengan Indikator : Partisipasi Uang, Partisipasi Harta Benda, Partisipasi Tenaga, Partisipasi Keterampilan, Partisipasi Buah Pikiran, Partisipasi Sosial.

Tabel 1. Tanggapan Responden tentang Partisipasi Uang

\begin{tabular}{|c|l|c|c|}
\hline No & \multicolumn{1}{|c|}{$\begin{array}{c}\text { Jawaban } \\
\text { Responden }\end{array}$} & $\begin{array}{c}\text { Frekue } \\
\text { nsi }\end{array}$ & Persentase \\
\hline 1 & Berpartisipasi & 5 & 5,68 \\
\hline 2 & $\begin{array}{l}\text { Berpartisipasi } \\
\text { jika diminta }\end{array}$ & 10 & 11,36 \\
\hline 3 & $\begin{array}{l}\text { Tidak } \\
\text { berpartisipasi }\end{array}$ & 73 & 82,96 \\
\hline & Jumlah & $\mathbf{8 8}$ & $\mathbf{1 0 0}$ \\
\hline
\end{tabular}

Sumber : Data Hasil Penelitian, 2019

Berdasarkan hasil jawaban responden dalam tabel 1 di atas dapat diketahui bahwa responden kurang berpartisipasi dalam bentuk uang. Responden yang tidak berpartisipasi dalam bentuk uang disebabkan karena ketidaktegasan kepala lingkungan dalam penarikan uang dari masyarakat. Selain itu, responden yang tidak berpartisipasi dikarenakan tingkat perekonomian yang masih rendah.

Hasil jawaban tersebut menunjukkan bahwa masih banyak 
masyarakat di Kelurahan Sukamenanti

Kecamatan Kedaton Bandar Lampung yang masih kurang berpartisipasi dalam bentuk uang.

Tabel 2. Tanggapan Responden tentang Partisipasi Harta

\begin{tabular}{|c|l|c|c|}
\hline No & $\begin{array}{c}\text { Jawaban } \\
\text { Responden }\end{array}$ & $\begin{array}{c}\text { Frekue } \\
\text { nsi }\end{array}$ & Persentase \\
\hline 1 & Berpartisipasi & 88 & 100 \\
\hline 2 & $\begin{array}{l}\text { Berpartisipasi } \\
\text { jika diminta }\end{array}$ & 0 & 0 \\
\hline 3 & $\begin{array}{l}\text { Tidak } \\
\text { berpartisipasi }\end{array}$ & 0 & 0 \\
\hline & Jumlah & $\mathbf{8 8}$ & $\mathbf{1 0 0}$ \\
\hline
\end{tabular}

Sumber : Data Hasil Penelitian, 2019

Berdasarkan hasil jawaban responden dalam tabel 2 di atas dapat diketahui bahwa responden sangat berpartisipasi dalam bentuk harta. Kerukunan yang dibina di Kelurahan Sukamenanti sangatlah tinggi, hal tersebutlah yang membuat warga senantiasa rela untuk memberikan sebagian harta benda mereka dalam menjaga sistem keamanan lingkungan atau siskamling.

Hasil jawaban tersebut menunjukkan bahwa masyarakat di Kelurahan Sukamenanti Kecamatan Kedaton Bandar Lampung sangat berpartisipasi dalam bentuk harta untuk kepentingan sistem keamanan lingkungan atau siskamling.
Tabel 3. Tanggapan Responden tentang Partisipasi Tenaga

\begin{tabular}{|c|l|c|c|}
\hline No & \multicolumn{1}{|c|}{$\begin{array}{c}\text { Jawaban } \\
\text { Responden }\end{array}$} & $\begin{array}{c}\text { Frekue } \\
\text { nsi }\end{array}$ & Persentase \\
\hline 1 & Berpartisipasi & 66 & 75 \\
\hline 2 & $\begin{array}{l}\text { Berpartisipasi } \\
\text { jika diminta }\end{array}$ & 20 & 22,72 \\
\hline 3 & $\begin{array}{l}\text { Tidak } \\
\text { berpartisipasi }\end{array}$ & 2 & 2,27 \\
\hline & Jumlah & $\mathbf{8 8}$ & $\mathbf{1 0 0}$ \\
\hline
\end{tabular}

Sumber : Data Hasil Penelitian, 2019

Berdasarkan hasil jawaban responden dalam tabel 3 di atas dapat diketahui bahwa responden sangat berpartisipasi dalam bentuk tenaga. Responden yang tidak dapat berpartisipasi beralasan bahwa mereka memiliki kegiatan yang sangat padat dan kelelahan.

Hasil jawaban tersebut menunjukkan bahwa sudah sangat banyak masyarakat di Kelurahan Sukamenanti Kecamatan Kedaton Bandar Lampung yang berpartisipasi dalam bentuk tenaga.

Tabel 4. Tanggapan Responden tentang Partisipasi Keterampilan

\begin{tabular}{|c|l|c|c|}
\hline No & \multicolumn{1}{|c|}{$\begin{array}{c}\text { Jawaban } \\
\text { Responden }\end{array}$} & $\begin{array}{c}\text { Frekue } \\
\text { nsi }\end{array}$ & Persentase \\
\hline 1 & Berpartisipasi & 88 & 100 \\
\hline 2 & $\begin{array}{l}\text { Berpartisipasi } \\
\text { jika diminta }\end{array}$ & 0 & 0 \\
\hline 3 & $\begin{array}{l}\text { Tidak } \\
\text { berpartisipasi }\end{array}$ & 0 & 0 \\
\hline & Jumlah & $\mathbf{8 8}$ & $\mathbf{1 0 0}$ \\
\hline
\end{tabular}

Sumber : Data Hasil Penelitian, 2019 
Berdasarkan hasil jawaban responden dalam tabel 4 di atas dapat diketahui bahwa responden sangat berpartisipasi dalam bentuk keterampilan. Banyaknya responden yang berpartisipasi beranggapan bahwa keamanan lingkungan adalah tugas bersama yang harus selalu dilaksanakan.

Hasil jawaban tersebut menunjukkan bahwa masyarakat di Kelurahan Sukamenanti Kecamatan Kedaton Bandar Lampung sangat berpartisipasi dalam bentuk keterampilan.

Tabel 5. Tanggapan Responden tentang Partisipasi Buah Pikiran

\begin{tabular}{|c|l|c|c|}
\hline No & \multicolumn{1}{|c|}{$\begin{array}{c}\text { Jawaban } \\
\text { Responden }\end{array}$} & $\begin{array}{c}\text { Frekue } \\
\text { nsi }\end{array}$ & Persentase \\
\hline 1 & Berpartisipasi & 50 & 56,82 \\
\hline 2 & $\begin{array}{l}\text { Berpartisipasi } \\
\text { jika diminta }\end{array}$ & 20 & 22,73 \\
\hline 3 & $\begin{array}{l}\text { Tidak } \\
\text { berpartisipasi }\end{array}$ & 18 & 20,45 \\
\hline & Jumlah & $\mathbf{8 8}$ & $\mathbf{1 0 0}$ \\
\hline
\end{tabular}

Sumber : Data Hasil Penelitian, 2019

Berdasarkan hasil jawaban responden dalam tabel 5 di atas dapat diketahui bahwa responden cukup berpartisipasi dalam bentuk buah pikiran. Banyaknya responden yang berpartisipasi dikarenakan oleh maraknya kriminalitas yang terjadi.

Hasil jawaban tersebut menunjukkan bahwa masyarakat di
Kelurahan Sukamenanti Kecamatan Kedaton Bandar Lampung berpartisipasi dalam bentuk buah pikiran.

Tabel 6. Tanggapan Responden tentang Partisipasi Sosial

\begin{tabular}{|c|l|c|c|}
\hline No & \multicolumn{1}{|c|}{$\begin{array}{c}\text { Jawaban } \\
\text { Responden }\end{array}$} & $\begin{array}{c}\text { Frekue } \\
\text { nsi }\end{array}$ & Persentase \\
\hline 1 & Berpartisipasi & 88 & 100 \\
\hline 2 & $\begin{array}{l}\text { Berpartisipasi } \\
\text { jika diminta }\end{array}$ & 0 & 0 \\
\hline 3 & $\begin{array}{l}\text { Tidak } \\
\text { berpartisipasi }\end{array}$ & 0 & 0 \\
\hline & Jumlah & $\mathbf{8 8}$ & $\mathbf{1 0 0}$ \\
\hline
\end{tabular}

Sumber : Data Hasil Penelitian, 2019

Berdasarkan hasil jawaban responden dalam tabel 6 di atas dapat diketahui bahwa responden sangat berpartisipasi dalam bentuk partisipasi sosial. Hasil jawaban tersebut menunjukkan masyarakat di Kelurahan Sukamenanti Kecamatan Kedaton Bandar Lampung sangat berpartisipasi dalam bentuk partisipasi sosial.

Berdasarkan hasil penelitian dan perhitungan data menggunakan bantuan tabel distribusi frekuensi maka diketahui bahwa bentuk partisipasi masyarakat dalam Pelaksanaan Sistim Keamanan Lingkungan atau siskamling di Kelurahan Sukamenanti Kecamatan Kedaton Kota Bandar Lampung masuk dalam kategori tinggi. 
Tingginya tingkat partisipasi masyarakat dalam pelaksanaan Sistim Keamanan Lingkungan di Kelurahan Sukamenanti Kecamatan Kedaton Kota Bandar Lampung tersebut dapat berkaitan dengan pengetahuan dan kesadaran masyarakat mengenai pentingnya menjaga keamanan dan ketertiban lingkungan tempat tinggal.

Hal ini sesuai dengan pendapat yang dikemukakan Oktariani (2004: 15), bahwa partisipasi adalah suatu sistem terhadap masalah yang dihadapi dan pemecahannya dalam pembangunan suatu bidang.

Partisipasi merupakan keterlibatan seseorang pada bagian kegiatan bersama atau sebagai penyertaan mental dan energi seseorang dalam kelompok untuk menyumbangkan pemikiran dan perasaan sehingga tujuan dapat dicapai dan sekaligus mempertanggung jawabkannya. Dalam hal ini partisipasi diaplikasikan pada kegiatan Siskamling atau sistem keamanan lingkungan.

\section{Keamanan dan Ketertiban Masyarakat}

Keamanan dan Ketertiban Masyarakat mengandung 4 (empat) pengertian dasar, yaitu a) security yaitu perasaan bebas dari gangguan fisik dan psikis; b) surety yaitu perasaan bebas dari kekhawatiran; c) safety yaitu perasaan terlindung dari segala bahaya; dan d) peace yaitu perasaan damai lahiriah dan batiniah.

Tabel 7. Tanggapan Responden tentang Gangguan Fisik dan Psikis

\begin{tabular}{|c|l|c|c|}
\hline No & \multicolumn{1}{|c|}{$\begin{array}{c}\text { Jawaban } \\
\text { Responden }\end{array}$} & $\begin{array}{c}\text { Frekue } \\
\text { nsi }\end{array}$ & Persentase \\
\hline 1 & Ada & 0 & 0 \\
\hline 2 & Jarang terjadi & 0 & 0 \\
\hline 3 & Tidak ada & 88 & 100 \\
\hline & Jumlah & $\mathbf{8 8}$ & $\mathbf{1 0 0}$ \\
\hline
\end{tabular}

Sumber : Data Hasil Penelitian, 2019

Berdasarkan hasil jawaban responden dalam tabel 7 di atas dapat diketahui bahwa responden tidak mengalami gangguan fisik dan psikis. Tidak adanya gangguan secara fisik dan psikis dikarenakan adanya patroli dari pemolisian masyarakat (polmas).

Tabel 8. Tanggapan Responden tentang Kekhawatiran

\begin{tabular}{|c|l|c|c|}
\hline No & $\begin{array}{c}\text { Jawaban } \\
\text { Responden }\end{array}$ & $\begin{array}{c}\text { Frekue } \\
\text { nsi }\end{array}$ & Persentase \\
\hline 1 & Ada & 8 & 9,09 \\
\hline 2 & Sedikit & 16 & 18,18 \\
\hline 3 & Tidak ada & 64 & 72,72 \\
\hline & Jumlah & $\mathbf{8 8}$ & $\mathbf{1 0 0}$ \\
\hline
\end{tabular}

Sumber : Data Hasil Penelitian, 2019

Berdasarkan hasil jawaban responden dalam tabel 8 di atas dapat diketahui bahwa responden tidak memiliki perasaan kekhawatiran. Responden yang menyatakan tidak adanya kekhawatiran dikarenakan 
adanya pemolisian masyarakat (polmas) yang selalu berjaga. Kekhawatiran yang paling ditakutkan adalah kejahatan dengan menggunakan senjata api.

Hasil jawaban tersebut menunjukkan bahwa hanya terdapat sedikit kekhawatiran akan keamanan dan ketertiban di Kelurahan Sukamenanti Kecamatan Kedaton Bandar Lampung.

Tabel 9. Tanggapan Responden tentang Terlindungi dari Segala Bahaya.

\begin{tabular}{|c|l|c|c|}
\hline No & $\begin{array}{c}\text { Jawaban } \\
\text { Responden }\end{array}$ & $\begin{array}{c}\text { Frekue } \\
\text { nsi }\end{array}$ & Persentase \\
\hline 1 & Ada pencurian & 0 & 0 \\
\hline 2 & $\begin{array}{l}\text { Jarang terjadi } \\
\text { pencurian }\end{array}$ & 0 & 0 \\
\hline 3 & $\begin{array}{l}\text { Tidak ada } \\
\text { pencurian }\end{array}$ & 88 & 100 \\
\hline & Jumlah & $\mathbf{8 8}$ & $\mathbf{1 0 0}$ \\
\hline
\end{tabular}

Sumber : Data Hasil Penelitian, 2019

$$
\text { Berdasarkan hasil jawaban }
$$
responden dalam tabel 9 di atas dapat diketahui bahwa responden telah terlindungi dari bahaya pencurian. Hasil jawaban tersebut menunjukkan bahwa masyarakat masih telah terlindungi dari segala bahaya di Kelurahan Sukamenanti Kecamatan Kedaton Bandar Lampung terutama dalam hal pencurian.
Tabel 10. Tanggapan Responden tentang Rasa Damai Lahiriah dan Batiniah

\begin{tabular}{|c|l|c|c|}
\hline No & \multicolumn{1}{|c|}{$\begin{array}{c}\text { Jawaban } \\
\text { Responden }\end{array}$} & $\begin{array}{c}\text { Frekue } \\
\text { nsi }\end{array}$ & Persentase \\
\hline 1 & Tidak rukun & 18 & 20,45 \\
\hline 2 & Sedikit rukun & 20 & 22,73 \\
\hline 3 & Rukun & 50 & 56,82 \\
\hline & Jumlah & $\mathbf{8 8}$ & $\mathbf{1 0 0}$ \\
\hline
\end{tabular}

Sumber : Data Hasil Penelitian, 2019

Berdasarkan hasil jawaban responden dalam tabel 10 di atas dapat diketahui bahwa responden sudah merasa damai baik secara lahiriah maupun bathiniah, Kerukunan yang terjadi disebabkan oleh keakraban yang terjalin pada setiap kegiatan. Hasil jawaban tersebut menunjukkan bahwa masyarakat di Kelurahan Sukamenanti Kecamatan Kedaton Bandar Lampung hidup rukun baik secara lahiriah maupun bathiniah.

Tanggung jawab masyarakat sebagai wujud partisipasinya dalam memelihara dan menjaga keamanan dan ketertiban yaitu dengan jalan ikut serta bertanggung jawab terhadap keamanan dan ketertiban seluruh anggota masyarakat di mana tempat ia tinggal, sehingga dapat terpeliharanya ketertiban dan keamanan lingkungan.

Uraian di atas sesuai dengan pendapat Awaloeddin (2003: 160), bahwa untuk memelihara dan sekaligus menciptakan keamanan dan ketertiban 
masyarakat, masyarakat harus ikut aktif berpartisipasi, sedangkan untuk pelaksanaan sistim keamanan dan ketertiban lingkungan ini yang merupakan salah satu tugas pokok Polri sebagai pembina, dengan lebih memfungsikan para Babinhantibnas di tiap-tiap kelurahan/desa sebagai ujung tombak dan sekaligus Pembina masyarakat desa dalam hal keamanan dan ketertiban lingkungan.

\section{SIMPULAN DAN SARAN}

\section{Simpulan}

Partisipasi masyarakat dalam Pelaksanaan Sistem Keamanan Lingkungan di Kelurahan Sukamenanti Kecamatan Kedaton Kota Bandar Lampung telah berperan aktif dalam meningkatkan ketertiban dan keamanan. Pada pelaksanaannya masyarakat telah berpartisipasi dalam proses pelaksanaan Sistim Keamanan Lingkungan dalam berbagai bentuk.

Menjaga keamanan lingkungan merupakan tanggung jawab bersama, selain pihak kepolisian sebagai inti kekuatan dan sekaligus sebagai pembina keamanan dan ketertiban salah satu bagian terpenting dalam pemeliharan keamanan lingkungan adalah peran serta masyarakat itu sendiri.

\section{Saran}

Dalam rangka lebih mengefektifkan wujud partisipasi masyarakat dalam usaha memelihara, menjaga keamanan dan ketertiban masyarakat, pihak kepolisian sebagai inti kekuatan dan sekaligus sebagai pembina keamanan dan ketertiban masyarakat berkoordinasi dengan aparat pemerintah lainnya, agar pembinaan terhadap mayarakat dapat membuahkan hasil yang diharapkan, yaitu terciptanya keamanan dan ketertiban di dalam masyarakat.

Dalam upaya melakukan pembinaan keamanan dan ketertiban terhadap masyarakat, Polri dapat memberikan kegiatan-kegiatan seperti penyuluhan, penerangan, komunikasi ataupun berbagai macam kegiatan lainnya. Dalam pembinaan ini Polri khususnya babinkamtibmas harus bersikap proaktif, tidak menunggu dari masyarakat, karena kehidupan masyarakat sekarang ini sudah mengalami pergeseran, sudah tidak saling peduli antara sesama atau tidak mau tau apa yang terjadi disekitar. 


\section{DAFTAR PUSTAKA}

Adi, I, R,. (2007). Perencanaan Partisipatoris Berbasis Aset Komunitas dari Pemikiran Menuju Penerapan. Depok: FISIP UI Press.

Arikunto, S. (1993). Prosedur Penelitian Suatu Pendekatan Praktek. Jakarta: Rineka Cipta.

Awaloeddin, Musa. (2003). Interaksi dalam partisipasi. Jakarta: Pelita Ilmu.

Hamijoyo, (2007). Partisipasi Dalam Pembangunan. Jakarta: Depdikbud RI.

Kartono, K. (1993). Pengantar Metodologi Research Sosial, Bandung: Alumni.

Koentjaraningrat. (1994) Metode Penelitian Masyarakat. Jakarta: Gramedia.

Mabes Polri. (2003) Prosedur operasional sistem keamanan lingkungan. Jakarta.

Nasikun, A. (2003). Mewujudkan partisipasi masyarakat. Jakarta: Yayasan Insan Cipta Media.

Nasution, S. (1992). Metode Research, Bandung: Jemmars.

Riduwan. (2004). Metode dan Teknik Menyusun Tesis. Cetakan Pertama. Bandung: Alfabeta.

Singarimbun, M. (1991) Metode Penelitian dan Survey. Jakarta: Rajawali.

Sugiyono. (2009). Metode Penelitian Kuantitatif Kualitatif Dan $R \& D$. Bandung : Alfabeta.
Surahmad, W. (2010) Pengantar Penelitian Ilmiah, Bandung: Tarsit

Suryabrata, S. (1997) Metodologi Research, Jogjakarta: Yayasan Penerbitan Fakultas Psikologi UGM.

Tjahya. S, U. (2000). Strategi Pembangunan dan Kemiskinan. Jakarta: PT. Rineka Cipta. 